\title{
Nigerian Governors Get Jittery When "State of Emergency" Is Mentioned: A Juristic Overview of S.305 of the Constitution of the Federal Republic of Nigeria, 1999 as Amended
}

\author{
Benjamin 0. Igwenyi*, Chinwe C. Nwogbo-Egwu, Chinedu A. Igwe \\ Department of Public and Private Law, Ebonyi State University, Abakaliki, Nigeria \\ Email: `benigwenyi@gmail.com, decordys@gmail.com, legaljournal2016@yahoo.com
}

How to cite this paper: Igwenyi, B. O., Nwogbo-Egwu, C. C., \& Igwe, C. A. (2019). Nigerian Governors Get Jittery When "State of Emergency" Is Mentioned: A Juristic Overview of S.305 of the Constitution of the Federal Republic of Nigeria, 1999 as Amended. Beijing Law Review, 10, 1346-1355.

https://doi.org/10.4236/blr.2019.105072

Received: September 27, 2019

Accepted: December 17, 2019

Published: December 20, 2019

Copyright $\odot 2019$ by author(s) and Scientific Research Publishing Inc. This work is licensed under the Creative Commons Attribution International License (CC BY 4.0).

http://creativecommons.org/licenses/by/4.0/

\begin{abstract}
The Constitution of the Federal Republic of Nigeria, 1999 as amended empowers the country's President in section 305 to declare a State Emergency in the whole country or any part thereof if the country is involved in any crisis situation caused by either human beings or natural phenomena such as earthquake, floods, erosion etc. The essence of this provision is to enable the president to restore peace and order during that period of emergency after which normalcy will return. The International Convent on Civil and Political Rights 1966 (ICCPR) of the United Nations allows countries to declare state of emergency which will involve taking measures to solve either man-made or natural exigencies and to return the country immediately to constitutional order as soon as the emergency is over. Purportedly, acting under section 305 as aforementioned, two former Presidents of Nigeria in 2004, 2006 and 2013 declared state of emergencies in 5 (five) states of the country. In the 2004 and 2006 events, President Olusegun Obasanjo in declaring state of emergency in Plateau State and Ekiti State respectively suspended the Governors of the 2 (two) states and their Houses of Assembly for 6 (six) months and appointed former military officers to act as Administrators of the States. In the 2013 event, President Goodluck Jonathan declared state of emergency in Adamawa, Yobe and Borno States because of the activities of Boko Haram extremists in the region but did not suspend democratic structures. As a result of the events in the states where state of emergency had been declared in Nigeria in the past, sitting Governors and their Houses of Assembly live and work in fear whenever the word "state of emergency" is mentioned with regard to their States. This paper argues, using historical and doctrinal methods that section 305 of the Constitution does not give the President power to suspend
\end{abstract}


any Governor or prevent the Houses of Assembly from performing their functions because of state of emergency and suggests that section 305 (3) should be amended to state clearly what the President should do in each occasion whenever a state of emergency is declared either because of natural disaster or civil disobedience in the country, instead of leaving the President to do whatever he wants whenever he declares state of emergency.

\section{Keywords}

State of Emergency, Proclamation, Constitution, Amendment, Normalcy

\section{Introduction}

Section 305 (1) of the Constitution of the Federal Republic of Nigeria, 1999 as amended provides as follows: subject to the provision of this Constitution, the President may by instrument publish in the Official Gazette of the Government of the Federation issue a proclamation of a state of emergency in the Federation or any part thereof. In subsection 2 of the same, the President shall immediately after the publication, transmit copies of the official gazette of the Government of the Federation containing the proclamation, including the details of the emergency to the President of the Senate and the Speaker of the House of Representatives who in their two chambers with their members will decide whether or not to pass a resolution approving the proclamation. This approval should be done within two days if the Houses are in session or within ten days if they are not in session.

Section 305 (3) enumerates the situations when the President may declare state of emergency and they include: when the federation is at war or where the federation is in imminent danger of invasion or involvement in a state of war, when there is actual break down of public order or public safety in the whole country or any part, when there is clear and present danger of an actual breakdown of public order and public safety or any public danger which clearly constitutes a threat to the existence of the federation or where the president receives a request from a State Governor asking him to declare a state of emergency in the Governor's State which request must be accompanied by a resolution of the State House of Assembly.

In the year 2004, the then sitting President of Nigeria, Chief Olusegun Obasanjo declared state of emergency in Plateau State, removing the State Governor, Mr. Joshua Dariye and suspended the House of Assembly too for six months (Nwabueze, 2004). In the year 2006, the same President repeated the exercise in Ekiti State whereof he removed a sitting Governor Peter Ayodele Fayose and his Deputy, Mrs. Abiodun Olujimi and replaced them with retired Army General, Tunji Olurin for a period of six months (Aluko, 2006). In 2013, President Goodluck Jonathan declared state of emergency in Adamawa, Borno and Yobe States ravaged by Boko Haram insurgency, but was somehow consti- 
tutional in action as he did not suspend the Governors and the Houses of Assembly as done by Obasanjo in the above two cases (Rose, 2013).

The International Covenant on Civil and Political Rights 1966 in Article 4 empowers state parties to declare state of emergency subject to certain rules which do not include dissolution of democratic structures in a country. As a result of the events in Nigeria in recent times, State Governors get jittery when there is any threat to declare state of emergency in their states. Recently, the former Governor of Zamfara State, Mr. Abdulaziz Yari was quoted as expressing his willingness to sacrifice his position as a Governor if state of emergency was declared in his state provided insurgents in his state would be flushed out by soldiers (Taiwo-Obalonye, 2019).

The purport of this research is therefore to allay the fears of Governors, State House of Assembly Members and in fact other political office holders in the country on the implications of declaration of state of emergency in deserving situations. That is to say that declaration of state of emergency does not involve dismantling democratic structures but mere curtailing of some fundamental rights of citizens while it lasted.

In order to give comprehensive attention to this paper, we shall first discuss the meaning of state of emergency or emergency powers, the history of state of emergency in Nigeria, especially since 1999, a little comparism between state of emergency in Nigeria and other jurisdictions and we then make our recommendations to avoid a situation where the same type of incidents produces different reactions from different presidents.

\section{The Concept of State of Emergency and or Emergency Powers}

State of emergency which is synonymous with emergency powers appears to be better described or explained because even the constitution of Nigeria merely describes it. Simply it means a situation where the highest state authority takes steps to prevent a breakdown of law and order in the whole or part of the country where there is monumental natural disaster or man-made activity which threatens the existence of the whole country or any part thereof. According to authors of the Concise Oxford English Dictionary, $11^{\text {th }}$ Edition (Soanes and Stevenson, 2004), state of emergency is a situation of national danger or disaster in which a government suspends normal constitutional procedures. Also to be inferred is that emergency powers mean powers arising from emergency situation or powers used during emergency. That is to say that emergency powers are powers used when an unexpected and potentially dangerous situation which requires immediate action takes place in a country (Soanes and Stevenson, 2004).

Another definition given of emergency powers under the Civil Contingencies Act, 2004 of the Unite Kingdom is worthy of mention here. According to an author (Woodley, 2005) emergency powers confers powers on Ministers to make emergency regulations if an emergency has occurred, is occurring or is about to 
occur. The emergency event or situation may occur or be inside or outside the United Kingdom. An emergency event is an event or situation which threatens serious damage to human welfare or the environment in a place in the United Kingdom or war or terrorism which threatens serious damage to the security of the United Kingdom.

Another definition of emergency powers is that proffered in the Oxford Dictionary of Law which states that emergency powers means powers conferred by government regulations during a state of emergency. The existence of such a state is described by royal proclamation under the Emergency Powers Act, 1920 and 1964 and the Civil Contingencies Act 2004. A proclamation, which lasts for one month but is renewable, may be issued whenever there is a threat (e.g., a major strike or national disaster) to the country's essentials of life. The regulations made may confer on government departments, the armed forces and others all powers necessary to secure the supply and distribution of necessities and maintenance of public peace and safety (Martin and Law, 2006).

Conclusively, on what we mean by state of emergency, section 45 (3) of Constitution states that: in this constitution, a "period of emergency" means any period during which there is in force a proclamation of a state of emergency declared by the President in exercise of the power conferred on him under section 305 of the Constitution: That is why we stated at the commencement of this paper that the Constitution itself does not help as to the definition of what is state of emergency but what we can take from the above views expressed by scholars is that a state of emergency is declared by the highest state authority in a place where there is threat to the existence of the country or part thereof arising from man-made or natural phenomenon. A state of emergency is a temporal situation where few human rights are suspended to enable government handle the emergency and restore situation to normalcy.

\section{Emergency Power in Nigeria in Historical Perspectives}

The history of the use of emergency powers in Nigeria can be traced to what happened in old Western Region of Nigeria in 1962. According to a historian, it was political disagreements between the leaders of the Action Group (AG) party, that is, Chief Obafemi Awolowo and Chief Samuel Ladoke Akintola in May, 1962 that led to the declaration of state of emergency by the then Federal Government under Prime Minister Alhaji Tafewa Balewa (Adeeko, 2017). The same view was expressed by another scholar of Yoruba history (Teniola, 2017). According to the story, the disagreement between Chief Awolowo who was the leader of the A.G. and his deputy and Premier of Western Region, Chief S.L. Akintola led to division in the party at both National and Regional levels: Chief S.L. Akintola was expelled from the party. Members of the Western Regional House of Assembly passed a vote of no confidence on the Premier and this led to violent attacks on the floor of the House of Assembly and killings and destruction of property by opposing supporters of the two leaders. Hence, the nickname 
"Wild Wild West" was given to the Region.

Following the vote of no confidence on the Premier, the then Regional Governor Sir, Adesoji Aderemi demanded that the Premier should resign from office which the Premier refused. The Governor then appointed Alhaji Dauda Adegbenro as the new Premier of the Region and this brought the crisis to a crescendo and the whole of the Region was burning. Chief S.L. Akintola went to court to challenge his removal in the popular case of Akintola v. Adesoji Aderemi (1962) whereof the Supreme Court of Nigeria restored him to office, contending that the removal of the Premier by the members of the House of Assembly was based on mere signatures of the members collected and not as a result of vote of members that took place in the floor of the House of Assembly.

Alhaji Dauda Adegbenro, the sitting Premier appealed to the Privy Council in London in the case of D.S. Adegbenro v. Chief S.L. Akintola, (1963) where the then apex court for the country held that the removal of Chief S.L. Akintola through the signatures of the two-third majority of members of the House of Assembly under section 33 (10) of the Regional Constitution (1960) was proper. But before this judgment, Chief S.L. Akintola had consolidated his position by amending section 33 (10) of the Western Regional Constitution 1960 and the crisis continued.

On the $29^{\text {th }}$ of June, 1962, the then Prime Minister acting under section 65 of the 1960 Constitution of the Federal Republic of Nigeria intervened and declared the first state of emergency in Nigeria; though he did not have power under that section to do what he did. He appointed Dr. Moses Majekodunmi as the Administrator or Interim Premier of the Region. It should be noted that section 65 of the 1960 Constitution did not empower the Prime Minister to remove or suspend elected state officials during state/period of emergency. This incident prepared the ground for what led to the first military coup on January 15, 1966, in Nigeria.

The second use of emergency powers in Nigeria was that done on $18^{\text {th }}$ May 2004 under President Olusegun Obasanjo who declared state of emergency in Plateau State (Nwabueze, 2007). The reason given by the President for declaration of state of emergency in Plateau State was alleged break down of law and order in Yelwa and Langtang Local Government Areas of the State which led to the death of over six hundred Muslims without the State Government containing the situation. The State Governor, Mr. Joshua Dariye, his Deputy and the House of Assembly were suspended for six months. A Retired Army General, Chris Ali was appointed as Interim Administrator of the State. The President purportedly acted under section 305 of the Constitution and under the Emergency Powers Act, 1961 which had become defunct by virtue of section 65 (2) of that Constitution by effluxion of time. He subsequently sent the proclamation to the National Assembly which quickly ratified it and the state of emergency was in force for six months.

The question that calls for answer is whether the President acted in the spirit 
of section 305 of the constitution. The said section provides: subject to the provisions of this constitution, the President may by instrument published in official gazette declare a state of emergency in a state. There was no evidence that any instrument was published in the official government gazette before the President went on air to declare state of emergency. Two, there is no subsection of section 305 of the Constitution that empowers the President to remove the Governor of a State under any guise, otherwise a Governor would not have been expected to invite the President to declare state of emergency under section 305 (4) when there is such need in his State. A State Governor can only be removed from office under section 188 of the Constitution through impeachment by members of the State House of Assembly. Three, under section 11 (4) of the Constitution the National Assembly has no power to remove Governor or Deputy Governor or concur to the removal of a Governor or Deputy Governor from office under any guise. The much the National Assembly can do is to legislate for the particular State when the House of Assembly is in crisis. So the ratification of the proclamation by the National Assembly was equally wrong. Four, apart from the fact that there is no part of section 305 that empowers the President to remove the Governor or Deputy Governor during a period of emergency, there is no subsection that empowers the President to appoint someone as Acting Governor or Acting Deputy Governor. It can be seen then that it is illogical for the President to suspend the Governor, Deputy Governor and State House of Assembly because there is state of emergency as he will not suspend himself if state of emergency is declared in the whole country or suspend the National Assembly because there is state of emergency in the whole country. Above all, the Armed forces and all security agencies in the country are controlled and owned by the Federal Government and the Federal Government ought to be blamed for any break down of law and order which is not controlled.

Commenting on this declaration of state of emergency in 2004, a legal luminary, (then alive) stated: that it follows from this that if there is break down of public order, the responsibility for blame (if any) must fall more on the Federal Government than on the State Government concerned and why should that not be so when the Federal Government controls all the armed forces, the public and state security agencies. And why should the members of the State Assembly for whom the people of Plateau State voted to make laws for the peace, order and good government be suspended (Williams, 2004).

The third in the series of the declaration of state of emergency in Nigeria came up on the $18^{\text {th }}$ of October, 2006 by the same President Olusegun Obasanjo who removed from office the then Governor of Ekiti State, Peter Ayodele Fayose and his Deputy, Mrs. Abiodun Olujimi from office following the alleged impeachment of the Governor by the House of Assembly, (Aluko, 2006). According to reports, the House of Assembly had "impeached" the Governor, Peter Ayodele Fayose at his instigation and the President appealed to the members of the House of Assembly to spare the Deputy Governor to stay on, but the house 
members refused and swore in their Speaker, Mr. Friday Aderemi as Acting Governor. The President got annoyed and declared state of emergency in the state, sacking the Governor and of course the House of Assembly as a whole. He subsequently appointed Retired General, Tunji Olurin as the Sole Administrator of Ekiti State. It should be noted that there was no breakdown of law and order in Ekiti State save that the Governor had frosty relationship with the President. The National Assembly as in the previous case erroneously ratified the state of emergency. Simply stated, what happened in Ekiti State in 2006 constituted a breach of the constitution by the President.

Finally, on the history of state of emergency in Nigeria, on $14^{\text {th }}$ May, 2013, President Goodluck Jonathan declared state of emergency in the three North-East States of Adamawa, Borno and Yobe because of the activities of insurgent known as Boko Haram, relying on section 305 of the Constitution. The reason for the declaration was to contain the activities of bandits called Boko Haram (Rose, 2013). In the case of this declaration by Jonathan, he complied substantially with section 305 of the Constitution as he did not suspend the Governors nor their Houses of Assembly but only directed security agents to derogate on some fundamental rights and freedoms. However, he did not publish the proclamation in a gazette before radio and television announcements. It was on the $20^{\text {th }}$ of May, 2013 that the proclamation came out and same was ratified on the $22^{\text {nd }}$ of May, 2013 by the National Assembly.

\section{Nigeria, International Covenant on Civil and Political Rights and Some Other Jurisdictions}

\subsection{International Covenant on Civil and Political Rights (ICCPR)}

As we pointed out at the commencement of this paper, the International Covenant on Civil and Political Rights (ICCPR) 1966 empowers states which are parties to it to declare state of emergency in deserving situations. Nigeria is a signatory to the Covenant and she is supposed to abide by the covenant. Article 4 (1) states that in a time of public emergency which threatens the nation and her existence, that state of emergency may be declared in which case the state party may take measures that are allowed by the covenant, provided that such measures are not inconsistent with their obligations under International Law and will not involve discrimination solely on the ground of race, colour, sex, language or social origin. Article 6 which relates to right to life, 7 which relates to right to dignity of human person, $8(1 \& 2)$ which relates to no slavery or servitude in any form are some of the rights that ICCPR prohibits states from breaching during state of emergency. Retroactive legislations are barred by Article 15 while Article 16 guarantees everyone right to be recognized as a human person and all these are non-derogable. According to the Covenant therefore, the above rights are available to every citizen even during period of state of emergency in any country that is party to the instrument. There is no where in the document that countries are allowed to touch these rights during emergency what 
more dismantling democratic structures.

\subsection{Nigerian Observance of ICCPR}

Section 45 of the 1999 Constitution provides in subsection 2 that there should be no derogation from the provisions of section 36 of the Constitution which deals with right to life except in the case of death resulting from acts of war and that no person should be punished retroactively under section 36 (8) of the Constitution. However, section 45 (1) of the Constitution allows the state to derogate on right to private and family life (section 37 ); right to freedom of thought, conscience and religion (section 38); right to freedom of expression and the press (section 39); right to peaceful assembly and association (section 40), and right to freedom of movement during period of emergency. In summary, the International Covenant which allows for state of emergency does not in any way allow state parties to go to the extent of dismantling democratic structures during state of emergency. That is why the focus of this paper is on the a normally that took place in Nigeria in 2004 and 2006 when the former President went beyond his power to suspend State Governors and Houses of Assembly because he declared state of emergency in those States

\subsection{State of Emergency in India}

Under the Constitution of India, that is sections 352 and 356; national emergencies may be proclaimed by the President in the whole or part of India in the period of war, armed rebellion or external aggression. This power was exercised in 1962 by the President during the China-India war. The same thing happened in 1971 during the Indo-Pakistani War and again between 1975-1977 in the political crisis between then Indian Prime Minister Indira Ghandi and her opponents, (Quora, 2019).

\subsection{State of Emergency in Sudan}

In Sudan, a State of emergency was recently declared in the country based on the country's constitution and it was as a result of protests by citizens of the country who wanted the President to step down, who had been on the throne since June 30, 1989. The President, Omar AI-Bashir had been in control and ruled draconically whereof he raised prices of goods and services to the discomfort of citizens. Because of the protests, he declared one year state of emergency on $22^{\text {nd }}$ of February, 2019. He was subsequently overthrown by soldiers and now facing trial (York, 2019). There was no elected official that was removed or suspended by the then President during the state of emergency.

\subsection{The American Example}

Conclusively, in the United States of America, they have been series of state of emergencies since 1976 since the National Emergencies Act was enacted. It was reported that in 1976 alone, USA declared 57 national emergencies and this is 
always done when there is any threat to state security including the popular 9/11 terrorist attack on USA (Struyk, 2019). In the light of the above, we can see that other countries declare state of emergency which normally involves curtailment of some fundamental rights and freedoms and does not involve dismantling or dissolving democratic structures in the name of state of emergency.

\section{Recommendations}

In the light of the foregoing, it is our recommendation that the following be done to make the law certain and predictable so that a sitting President at each particular time would know what to do while declaring a state of emergency in the whole or any part of the country without leaving him to his discretion.

First, that section 305 (3) of the Constitution should be amended to provide for what the President should do when he declares a state of emergency because the country is at war or what he should do if the country is in imminent danger of invasion or involvement in a state of war or what he should do when there is actual break down of public order or public safety or what he should do when he declares state of emergency on the occurrence of any natural disaster such as earthquake, flood or erosion that threatens the whole or any part of the country etc. This will clearly fix the President on what he should do when he is faced with any circumstance requiring the declaration of state of emergency as itemized in subsection 3 .

In addition, if there is this itemization of what the President should do in each case where and when he declares state of emergency, the ordinary citizen will know what he is to cope with during the period instead of guessing of what the President may do or may not do. The citizen will have rest of mind and prepare to cooperate with governmental authority in happiness.

Secondly, if the constitution cannot be amended because of the rigorous process involved, a new Emergency Powers Act should be enacted by the National Assembly which will be made pursuant to section 305 of the Constitution which will comprehensively treat in detail how the President could exercise his powers each time a state of emergency is declared in respect of the items enumerated in section 305 of the Constitution instead of leaving the President to guess on what to do. This will stop situations where Governor who belong to opposing political parties could be removed from office by the President during state of emergency while if the same thing happens in a State controlled by his political party, he would look the other way and nothing happens to such Governors because they are members of his party.

Additionally, the citizens will no longer read political meanings into the action of the President when he declares state of emergency as the new law will specify to the knowledge of political observers what piece of action the President will take whether the event is in a state under his party's control or not. It will create greater harmony for the enjoyment of democracy by all the citizens. 


\section{Conclusion}

Under international minimum standards, there must be certainty of existing laws and the benefits and punishments contained therein. Section 305 of 1999 Constitution is not certain and predictable. In 2004 and 2006, a sitting President of Nigeria declared state of emergency in two states and suspended the Governor, Deputy Governor and Houses of Assembly, because he thought he had right to do so. In 2013, another President declared state of emergency in three states and allowed democratic structures to be, because he thought that it was not necessary to dismantle the structures as there were complementary to the success of the state of emergency. The situation should not be allowed to be hanging like this. The law should be made certain so that the President should know what to do at each circumstance warranting a state of emergency.

\section{Conflicts of Interest}

The authors declare no conflicts of interest regarding the publication of this paper.

\section{References}

Adeeko, O. J. (2017). The Crisis That Truncated the First Republic.

Adegbenro, D. S., \& Akintola, S. L. (1963). 3 W.L.R 63 (P.C).

Akintola, S. L., \& Aderemi, A. (1962). W.N.L.R 185 S.C1.

Aluko, M. E. (2006). The State of Emergency in Ekiti State. https://dawodu.com

Martin, E. A., \& Law, J. (2006). Oxford Dictionary of Law (6th ed., p. 188). Oxford: Oxford University Press.

Nwabueze, B. O. (2004). The Rape of Constitutionality in Plateau. http://Dawodu.com

Nwabueze, B. O. (2007). Hon President Obasanjo Subverted Nigerian Federal System (p. 198). Ibadan: Gold Press Ltd.

Quora (2019). What Are the Emergency Powers of the President in India.

Rose, W. (2013). Nigeria's President Jonathan Declares State of Emergency.

Soanes, C., \& Stevenson, A. (2004) Concise Oxford English Dictionary (11th ed., p. 1409). New York: Oxford University Press.

Struyk, R. (2019). Trump’s Wall Would Be the 32nd Active National Emergency. http://edition-m.cnn.com

Taiwo-Obalonye, J. (2019). Insecurity: Am Ready to Quit. Daily Sun, Friday, January 4, 2019.

Teniola, E. (2017). How Balewa Declared State of Emergency in the West in 1962.

Williams, F. R. A. (2004). Obasanjo Acted Illegally (p. 5). Sunday Vanguard, May 23, 2004.

Woodley, M. (2005). Osborn's Concise Law Dictionary (10th ed., p. 156). London: Sweet and Maxwell.

York, G. (2019). Sudan's New Military Rulers Have No Plans to Extradict AL-Bashir, in Yet Another Rebuke of the International Criminal Court. 